\title{
INSPIREE:
}

\section{Efek Daya Ledak Otot Tungkai dan Motivasi Berprestasi dalam Keterampilan Smash pada Atlet Bola Voli}

d

https://doi.org/10.53905/inspiree.v1i2.12

*Yan Bastian ${ }^{\text {abcde }}$

${ }^{1}$ Sekolah Menengah Atas Negeri 1 Palmatak, Kabupaten Kepulauan Anambas, Kepulauan Riau.

\begin{abstract}
Tujuan Penelitian. Untuk mengetahui Pengaruh daya ledak otot tungkai dan motivasi berprestasi terhadap keterampilan smash bola voli pada Atlet Bola Voli Putra Klub Huha Pekanbaru

Metode Penelitian. Metode penelitian yang digunakan dalam penelitian ini adalah pendekatan kuantitatif, metode survei dengan teknik pengukuran dan tes. Sedangkan teknik analisis menggunakan pendekatan analisis jalur (path analysis) yaitu penelitian yang akan mengkaji atau menganalisis keterkaitan antar variabel penelitian.

Hasil. 1) Terdapat pengaruh langsung daya ledak otot $\left(X_{1}\right)$ terhadap hasil Keterampilan Smash Bola Voli (Y) sebesar 0,331. 2) Terdapat pengaruh langsung Motivasi Berprestasi $\left(\mathrm{X}_{2}\right)$ terhadap hasil Keterampilan Smash Bola Voli $(Y)$ sebesar 0,291. Hal ini terlihat pada Tabel Coffesient yang menunjukan nilai sig. 0,001. 3) Terdapat pengaruh langsung Daya Ledak Otot $\left(X_{1}\right)$ terhadap motivasi berprestasi $\left(X_{2}\right)$ sebesar 0,370 . Hal ini terlihat pada Tabel Coffesient yang menunjukan nilai sig. 0,000. Dan pengaruh total $X_{1}$ dan $X_{2}$ terhadap $Y$ sebesar $0,476=47,60 \%$.

Kesimpulan. Daya ledak otot dan motivasi berprestasi berpengaruh terhadap keterampilan smash bola voli atlet Putra Klub Huha Pekanbaru.
\end{abstract}

Published:

May 27, 2020

Kata Kunci: keterampilan smash bolavoli; daya ledak otot tungkai; motivasi berprestasi.

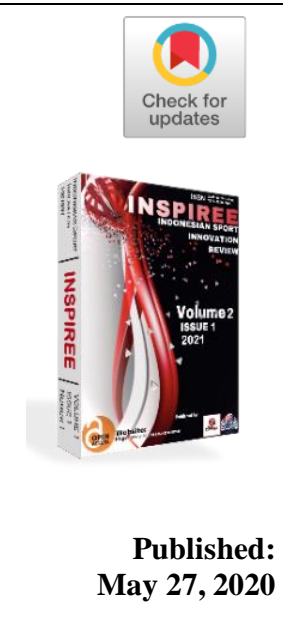

PENDAHULUAN

Olahraga bertujuan meningkatkan kualitas sumber daya manusia, sehingga pemerintah menjadikan olahraga sebagai sarana Pembangunan Nasional. Hal ini dapat dilihat dalam pasal 25 ayat 4 Undang-Undang Nomor 3 tahun 2005 tentang Sistem Keolahragaan Nasional bahwa: keolahragaan nasional bertujuan memelihara dan meningkatkan kesehatan, kebugaran, prestasi, kualitas manusia, menanamkan nilai moral dan akhlak mulia, sportivitas, disiplin, mempererat dan membina persatuan dan kesatuan bangsa, memperkokoh ketahanan nasional, serta mengangkat, harkat, martabat, dan kehormatan bangsa (Undang-Undang Nomor 3 tahun 2005). Olahraga prestasi disamping memiliki pengembangan peningkatan pengetahuan dan keterampilan teknis dibidang olahraga, atlet juga mendapatkan pembelajaran tentang nilai-nilai sosial yang positif serta dapat menanamkan sifat-sifat sportifitas yang tinggi 
sesuai dengan tujuan pendidikan olahraga tersebut. Salah satu olahraga yang dipertandingkan untuk mencapai tujuan tersebut adalah olahraga bola voli. Permainan bola voli merupakan suatu permainan yang kompleks yang tidak mudah dilakukan oleh setiap orang. Sebab, dalam permainan bola voli dibutuhkan koordinasi gerak yang benar-benar bisa diandalkan untuk melakukan semua gerakan yang ada didalam permainan bola voli (Ahmadi Nuril, 2007).

Dalam International Journal of Performance Analysis of Sport menyatakan Volleyball is differentiated from the rest of team sports, because although it is a sport with discrete skills (Palao, J.M, Santos, J.A, y Ureña, A., 2004). Dari teknik bola voli yang paling banyak disukai oleh para pemain maupun penonton adalah smash . smash adalah senjata dari setiap tim bola voli untuk melakukan penyerangan dalam mengumpulkan angka dan meraih kemenangan. Smash merupakan suatu keahlian yang esensial cara yang mudah untuk memenangkan angka (Dieter Beutelstahl, 2008).

Smash merupakan salah satu bentuk serangan dalam permainan bola voli, karakteristik bola hasil spike atau smash adalah menukik, tajam, dan cepat (Crisnan Hardian, 2011). Dalam istilah lain smash dapat disamakan dengan spike. Smash adalah suatu pukulan yang keras, lurus, tajam dan menukik seperti kita memaku; biasanya merupakan serangan dan mematikan. Teknik smash dalam permainan bola voli dapat di artikan sebagai cara memainkan bola dengan efisien dan efektif sesuai dengan peraturan permainan yang berlaku untuk mencapai suatu hasil yang optimal (Anandita F.P, 2010). Selanjutnya dalam jurnal nasional Smash adalah suatu upaya memasukan bola kedaerah lawan oleh pemain baris belakang yang berada di daerah Smash, untuk memukul bola dengan satu tangan atau lengan (I Made Suarsana, 2013). Sejalan dengan itu Ahmad Nuril (2007) berpendapat Pukulan keras atau smash merupakan bentuk serangan yang paling banyak dipergunakan dalam upaya memperoleh nilai oleh suatu tim. Dalam permainan bola voli terdapat 3 metode penyerangan yang dapat dikategorikan efektif, yaitu metode tip, smash pelan dan smash keras (Barbara L. Viera dan Bonnie Jill fergusson, 2000).

Salah satu unsur kondisi fisik yang memiliki peranan penting dalam kegiatan olahraga bola voli, baik sebagai unsur pendukung dalam suatu gerak maupun unsur utama dalam upaya pencapaian teknik gerakan yang sempurna adalah kekuatan (daya 
ledak). Secara fisikalis kekuatan sebagai kemampuan daya ledak (explosive power atau power), karena sudah memperhitungkan waktu atau tempo kecepatan gerakan (Syafrudin, 2011). Tudor O Bompa dan G. Gregory Haff (5 Edition) daya ledak adalah hasil dari dua kemampuan yaitu kecepatan maksimal dan kekuatan maksimal dalam waktu sesingkat mungkin. Specific programs to increase the explosive power of muscles have become important in volleyball, as it is clear that explosive power is crucial to optimal performance (Cedric Dupuis and Claire Tourny-Chollet, 2003).

Selain daya ledak otot tungkai faktor psikologi juga mempengaruhi keterampilan smash pada bola voli. yaitu motivasi berprestasi. Motivasi berprestasi merupakan salah satu penunjang untuk mencapai prestasi. Motivasi adalah dorongan yang timbul pada diri seseorang, secara disadari atau tidak disadari, untuk melakukan suatu tindakan dengan tujuan tertentu atau usaha-usaha yang dapat menyebabkan seseorang atau kelompok orang tertentu tergerak melakukan sesuatu karena ingin mencapai tujuan yang ingin dicapai (Mohammad Asrori, 2007). European Journal of Human Movement menyatakan bahwa, Motivation is the most important and immediate determinant of human behavior, then it awakens, energizes, directs and regulates it, making it a psychological mechanism that governs the direction, intensity and persistence of behavior (Fernando Claver, Ruth Jiménez, 2015). Menurut Britton W. Brewer (2009) Motivasi dapat didefinisikan sebagai arah dan intensitas usaha seseorang. Arah usaha mengacu pada apakah seseorang berusaha pendekatan atau tertarik pada situasi tertentu. Jadi motif artinya dorongan atau kehendak yang menyebabkan seseorang bertingkah laku. Dalam diri manusia terdapat motif yang bersifat alami yaitu motif individu manusia yang berusaha memenuhi kebutuhannya. Dari pengertian tersebut terdapat persamaan bahwa motivasi adalah pendorong/penggerak dalam diri manusia yang diarahkan untuk tujuan tertentu sesuai dengan kebutuhan dan pada akhirnya terlihat melalui tindakan/perbuatan yang dilakukan.

Motivasi berprestasi dalam diri seseorang berbeda-beda tergantung keperluan dan tujuan yang hendak dicapai. Dengan motivasi berprestasi yang tinggi seseorang berusaha untuk mencapai standar pencapaian yang tinggi. Masalah latar belakang sosial dan budaya juga akan mempengaruhi setiap individu terhadap motivasi berprestasinya, sehingga akan dijumpai tingkat motivasi dari masing-masing individu 
ada yang tinggi dan ada yang rendah karena perbedaan tersebut maka akan mempengaruhi hasil latihan yang dilaksanakan/pertandingan. Salah satu contohnya diungkapkan dalam jurnal researchgate publication diungkapkan bahwa, The results were not expected, although the decrease in the boys' desire for performance and success could perhaps be accounted for by the general fatigue that the players feel and the difficulty they have concentratiilg while working to accomplish a goal, and/or the decrease of motivation which is caused by success or failure to reach team goals as defined at the beginning of the season (Asterios Patsiaoulus, 2008). Motivasi merupakan sangat mempengaruhi kinerja olahraga khususnya kinerja olahraga permainan bola voli. Hal ini diungkapkan oleh Duda, Vallerand et all dalam Journal Of Sport \& Exercise Psychology, menyatakan, Motivation is at the heart of many of sport's most interesting problems, both as a developmental outcome of social environments such as competition and coaches' behaviors, and as a developmental influence on behavioral variables such as persistence, learning, and performance (Pelletier, Fortier et all, 1995).

Hasil penelitian tersebut menyimpulkan bahwa koordinasi mata-tangan dan motivasi berprestasi pengaruh positif terhadap keterampilan servis atas bola voli (Enjang Ahmad Mustaqim, 2015). Analysis, in which many strength and power qualities were observed to be significantly related with each other, these findings outline the interdependent nature of strength and power characteristic (Jeremy m. Sheppard, John b. Cronin Et All, 2008). It may be possible to perform a faster vertical velocity at takeoff by training jumping coordination. A faster vertical velocity is associated with a better jump height which could have good effects on the success in competition (Claas Kuhlmann, Karen Roemer, Thomas L. Milani, 2007).

\section{METODOLOGI PENELITIAN}

\section{Study participants}

Dalam penelitian ini yang digunakan sebagai populasi sasaran (target Population) penelitian adalah seluruh atlet bola voli Klub Huha Pekanbaru yang berjumlah 34 atlet.

\section{Study organization}

Metode penelitian yang digunakan dalam penelitian ini adalah pendekatan kuantitatif, metode survei dengan teknik pengukuran dan tes. Sedangkan teknik 
analisis menggunakan pendekatan analisis jalur (path analysis) yaitu penelitian yang akan mengkaji atau menganalisis keterkaitan antar variabel penelitian, serta mengukur pengaruh langsung antara satu variabel terhadap variabel lainnya. model path analysis digunakan untuk menganalisis pola hubungan antar variabel dengan tujuan untuk mengetahui pengaruh langsung seperangkat variabel bebas ( eksogen) terhadap variabel terikat (endogen). Variabel yang dikaji terdiri dari empat variabel yang terdiri dari tiga variabel eksogen (bebas) dan satu variabel endogen (terikat). Variabel eksogen terdiri dari daya ledak otot tungkai $\left(X_{1}\right)$, dan motivasi berprestasi $\left(X_{2}\right)$. Variabel endogen terdiri dari keterampilan smash bola voli (Y).

Testing procedure.

Teknik pengumpulan data yang akan digunakan dalam penelitian ini adalah: tes daya ledak otot tungkai, tes koordinasi mata-tangan, tes tingkat motivasi berprestasi, serta tes smash bola voli. Sesuai dengan jenis variabel-variabel yang dilibatkan dalam penelitian untuk mendapatkan data yang diolah dalam penelitian ini, maka instrumen yang digunakan adalah (1) instrumen smash bola voli $(\mathrm{Y})$ dengan menggunakan tes spike/ serangan, (2) instrumen daya ledak otot tungkai $\left(X_{1}\right)$ menggunakan tes daya ledak otot tungkai dengan Vertical Jump (Modified Sargnt jump), (3) instrumen motivasi berprestasi $\left(\mathrm{X}_{2}\right)$ menggunakan tes motivasi dengan angket. Instrumen penelitian akan dijelaskan satu persatu sebagai berikut :

\section{Instrumen Keterampilan Smash Bola Voli}

Aspek yang diukur dalam kemampuan smash bolavoli ini adalah proses dan produk, proses yang dinilai yaitu kualitas gerakan yang diberi skor total yang didapatkan dari atlit. unsur-unsur yang akan dites pada proses ini dimulai dari tahapan dari teknik smash itu sediri, dimulai dari (a) awalan, (b) tolakan melompat atau tolakan, (c) gerakan memukul bola, dan (d) mendarat. Sedangkan penilaian produknya terdiri atas arah hasil smash yang didberi angka pada lapangan bola voli. Instrumen keterampilan smash bolavoli ini bertujuan untuk mengukur teknik keterampilan smash, testee diberi kesempatan melakukan 5 kali teknik kemampuan smash. Dan data tes yang diambil adalah data tertinggi dari 5 kesempatan tersebut. Reliabelitas dalam instrumen ini dilakukan dengan cara uji coba instrumen yang dilakukan dengan karakter yang sama dengan sampel penelitian ini selanjutnya di ambil data yang telah 
di uji cobakan dan di olah data dalam ilmu statistik menggunakan rumus t-skor, hasil reliabelitasnya dilampirkan pada lampiran 1 hasil uji instrumen perhitungan sebagai berikut:

Equation 1. koefisien korelasi

Untuk menetukan validitas instrument menggunakan taraf signifikan 0,05. Butir pernyataan dikatakan valid jika koefisien korelasi $r_{h i t u n g}>t_{\text {table. }}$

Instrumen Daya Ledak Otot Tungkai $\left(X_{1}\right)$

Daya ledak otot tungkai adalah kualitas yang memungkinkan otot atau sekelompok otot untuk melakukan kerja fisik secara eksplosif dengan menggunakan vertical jump test yang masing-masing dilakukan sebanyak 3 kali pengukuran dan hasil terbaik yang di lingkari. Yang nanti hasil terbaik dari teste akan dicari rata total menggunakan t-score. Teste berdiri disamping tembok dimana pita pengukur berada. Memasukkan salah satu tangannya yang paling dekat dengan dinding/tembok kedalam kotak kapur atau kedalam air. Kemudian teste coba tegak, tangan yang telah dilumuri kapur angkat setinggi mungkin keatas dan sentuhkan jari itu ketembok, sampai terlihat dengan jelas bekasnya. Dalam hal ini, perlu diperhatikan bahwa teste sama sekali tidak dibenarkan untuk membengkokkan tubuhnya atau mengangkat tumitnya (jinjit). Bekas jari-jari tadi diukur dan dicatat. Berikut orang memulai dengan percobaannya dengan nampak jelas jari-jarinya. teste melakukan percobaan ini sampai tiga kali. Selisih antara tanda dalam sikap permulaan dan hasil loncatan tertinggi yang dijadikan nilai teste. Penilaian dari setiap testee yang melakukan adalah rentangan raihan tangan dengan jauhnya lompatan raihan. Hasil terbaik yang diambil sebagai data dari 3 kali pengukuran. Nilai diukur dengan satuan satuan satuan centimeter $(\mathrm{cm})$ dan akan dikonversi menggunakan t-score.

Instrumen Motivasi Berprestasi $\left(X_{2}\right)$

Dalam penelitian ini adalah informasi dari gejala psikologi yang timbul pada diri responden ketika melakukan keterampilan smash bola voli yang berkaitan dengan 
motivasi prestasi secara individu. Secara teori motivasi berprestasi mempunyai bebrapa konstruksi utama, Hal ini dijabarkan menurut pendapat Atkinson yaitu:1) Need for achievement (Keinginan/Kebutuhan untuk berprestasi). 2) Expectancies (harapan dan Impian). 3) Incentives (Bonus/penghargaan). 4) Approach success (pendekatan usaha untuk meraih kesuksesan)/avoid. 5) failure (usaha untuk menghindari kegagalan)

Informasi ini sendiri berupa tanggapan yang diberikan responden dengan pernyataan yang berupa angket. Rentang skor yang digunakan adalah 1-4. Proses dari penyusunan instrumen yang berupa kuesioner berjumlah 50\% pernyataan positif dan 50\% pernyataan Negatif serta diawali dengan kegiatan penentuan defenisi kontruksi utama motivasi berprestasi. Setelah itu dikembangkan menjadi butir-butir pernyataan beserta taraf skalanya. Angket yang disusun dengan menggunakan kuisioner dengan model skala likert. Model skala likert yang digunakan dalam instrumen ini adalah model skala likert yang dimodifikasi yaitu model skala dalam bentuk kontinu yang terdiri dari lima pilihan jawaban. Lebih rinci dijabarkan dalam bentuk tabel di bawah ini.

Tabel 1. Kriteria Pemberian Skor Pernyataan

\begin{tabular}{cccccc}
\hline Sifat & \multicolumn{5}{c}{ Kategori Jawaban dan Skor } \\
\cline { 2 - 6 } Pernyataan & SS & S & KS & TS & STS \\
\hline Positif & 5 & 4 & 3 & 2 & 1 \\
Negatif & 1 & 2 & 3 & 4 & 5 \\
\hline
\end{tabular}

Validitas instrumen motivasi berprestasi bersifat judgment oleh pakar dibidangnya. Selanjutnya melakukan kalibrasi instrumen dengan cara menganalisis data hasil dari uji coba untuk menentukan reliabilitasnya. Semua pertanyaan yang diujicobakan, dihitung yang memenuhi persyaratan sebagai butir pernyataan yang valid dan pernyataan dinyatakan gugur nantinya tidak akan digunakan lagi dalam instrumen penelitian.

\section{HASIL PENELITIAN}

\section{Deskripsi Data}

Berdasarkan penjelasan serta uraian yang telah dikemukakan sebelumnya, maka dalam bab ini akan dilakukan analisis deskriptif. Hasil penelitian akan digambarkan sesuai dengan tujuan hipotesis yang diajukan sebelumnya. Pada bagian ini akan dipaparkan deskripsi data penelitian Path Analisis yang merupakan hasil pengukuran terhadap seluruh subjek penelitian. 
Hasil Keterampilan Smash Bola Voli (Y)

Untuk memberikan gambaran tentang data mentah hasil keterampilan smash Bola Voli (Y) dapat disusun distribusi frekuensinya sebagai berikut :

Tabel 2. Daftar distribusi frekuensi hasil keterampilan smash bola voli

\begin{tabular}{cccccc} 
No & Interval Nilai & F & X & F.X & F Relatif \\
\hline 1 & $32,830-37,357$ & 4 & 35,0935 & 140,374 & $11,76 \%$ \\
2 & $37,358-41,885$ & 3 & 39,6215 & 118,8645 & $8,82 \%$ \\
3 & $41,886-46,413$ & 2 & 44,1495 & 88,299 & $5,88 \%$ \\
4 & $46,414-50,941$ & 5 & 48,541 & 242,705 & $14,71 \%$ \\
5 & $50,942-55,469$ & 14 & 53,2055 & 744,877 & $41,18 \%$ \\
6 & $55,470-60,220$ & 6 & 57,845 & 347,07 & $17,65 \%$ \\
\hline
\end{tabular}

Untuk lebih jelasnya dapat di lihat distribusi frekuensi tes hasil keterampilan smash bola voli adalah sebagai berikut:

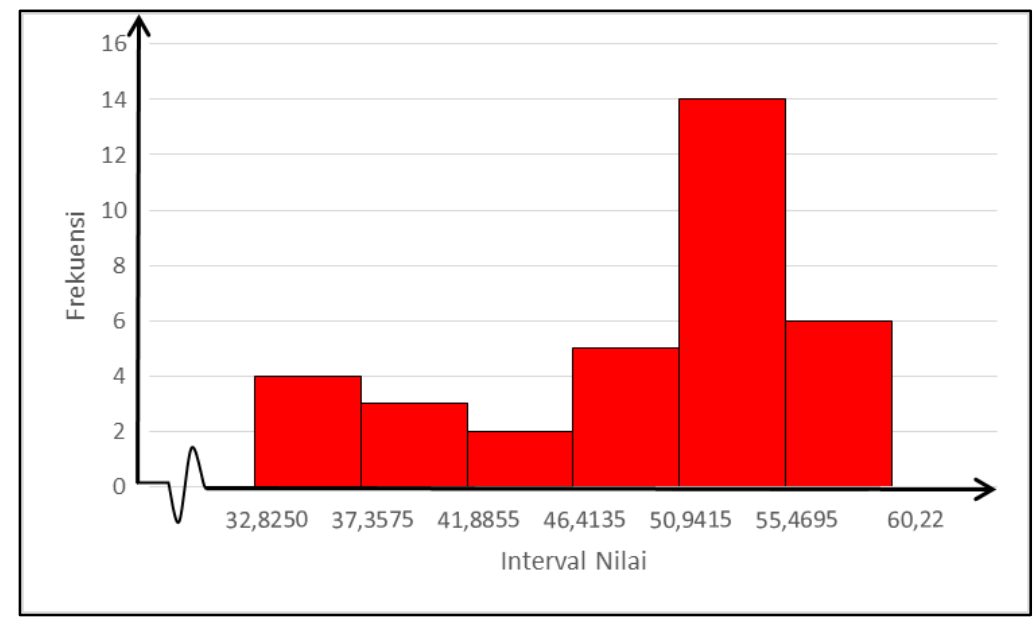

Grafik 1. Histogram keterampilan Smash Bola Voli

Hasil Daya Ledak Otot Tungkai $\left(X_{1}\right)$

Untuk memberikan gambaran tentang data mentah daya ledak otot tungkai $\left(\mathrm{X}_{1}\right)$ dapat disusun distribusi frekuensinya sebagai berikut :

Tabel 3. Daftar distribusi frekuensi daya ledak otot tungkai

\begin{tabular}{cccccc}
\hline No & Interval Nilai & F & X & F.X & F Relatif \\
\hline 1 & $56,00-60,792$ & 4 & 58,396 & 233,584 & $11,76 \%$ \\
2 & $60,793-65,585$ & 1 & 63,189 & 63,189 & $2,94 \%$ \\
3 & $65,586-70,378$ & 5 & 67,982 & 339,91 & $14,71 \%$ \\
4 & $70,379-75,171$ & 11 & 72,775 & 800,525 & $32,35 \%$ \\
5 & $75,172-79,964$ & 7 & 77,568 & 542,976 & $20,59 \%$ \\
6 & $79,965-85,00$ & 6 & 82,4825 & 494,9112 & $17,65 \%$ \\
\hline
\end{tabular}


Untuk lebih jelasnya dapat di lihat Histogram distribusi frekuensi tes hasil daya ledak otot tungkai adalah sebagai berikut:

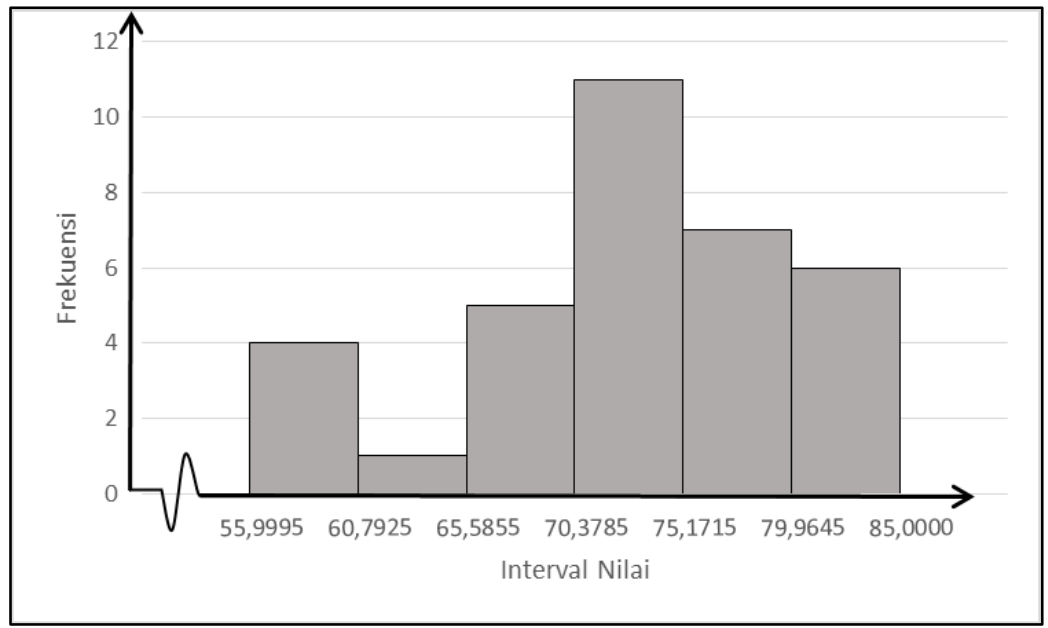

Grafik 2. Histogram Hasil Daya Ledak Otot Tungkai

Hasil Tes Motivasi Berprestasi $\left(X_{2}\right)$

Untuk memberikan gambaran tentang data mentah Motivasi Berprestasi $\left(X_{3}\right)$ dapat disusun distribusi frekuensinya sebagai berikut :

Tabel 4. Daftar distribusi frekuensi Motivasi Berprestasi

\begin{tabular}{|c|c|c|c|c|c|}
\hline No & Interval & $\mathbf{F}$ & $\mathbf{x}$ & fx & F Relatif \\
\hline 1 & $217,00-222,123$ & 6 & 219,5615 & 1317,369 & $17,65 \%$ \\
\hline 2 & $222,124-227,247$ & 3 & 224,6855 & 674,0565 & $8,82 \%$ \\
\hline 3 & $227,248-232,371$ & 7 & 229,8095 & 1608,6665 & $20,59 \%$ \\
\hline 4 & $232,372-237,495$ & 2 & 234,9335 & 469,867 & $5,88 \%$ \\
\hline 5 & $237,496-242,609$ & 6 & 240,0525 & 1440,315 & $17,65 \%$ \\
\hline 6 & $242,610-248,00$ & 10 & 245,305 & 2453,305 & $29,41 \%$ \\
\hline
\end{tabular}

Untuk lebih jelasnya dapat di lihat Histogram distribusi frekuensi tes hasil Motivasi Berprestasi adalah sebagai berikut:

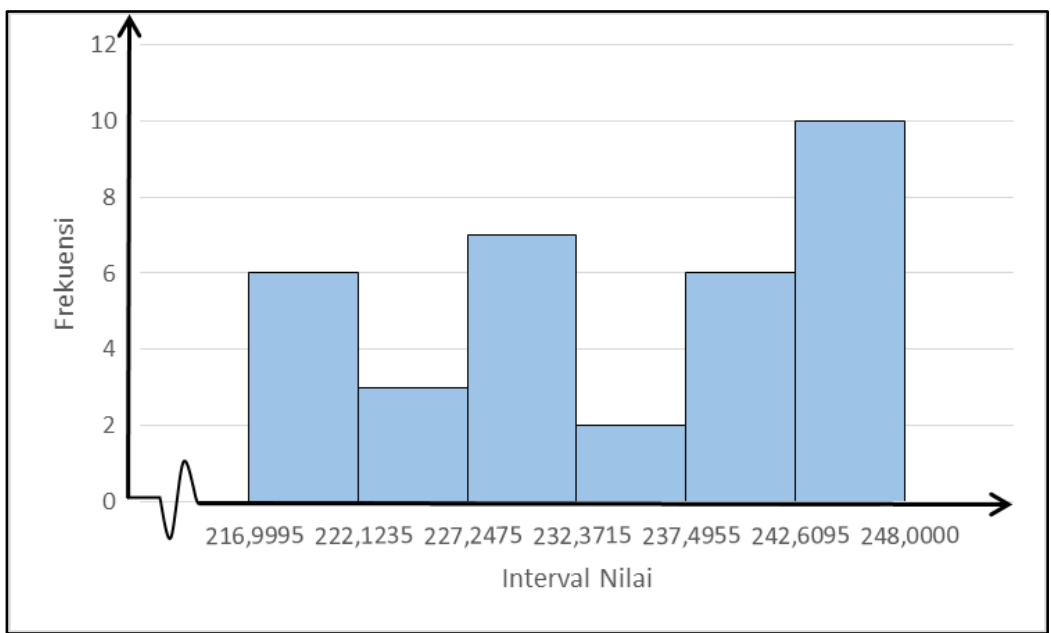

Grafik 3. Histogram Hasil Tes Motivasi Berprestasi 


\section{Pengujian Hipotesis}

$X_{1}$ Terhadap $Y$

Uji secara individual ditunjukkan oleh tabel Coeficients, bahwa hasil koefisien jalur $p_{y \times 1}=0,000$. Hipotesis penelitian yang akan diuji dirumuskan berbentuk hipotesis statistik sebagai berikut:

$$
\begin{aligned}
& \text { Ha: } p_{y x 1}>0 \\
& \text { Ho: } p_{y x 1}=0
\end{aligned}
$$

Hipotesis bentuk kalimat

Ha: Daya ledak otot tungkai berkontribusi terhadap Keterampilan Smash

Ho: Daya ledak otot tungkai tidak berkontrbusi terhadap Keterampilan Smash.

\begin{tabular}{|c|c|c|c|c|c|c|c|c|c|}
\hline \multirow[b]{2}{*}{ Model } & \multirow[b]{2}{*}{$\mathrm{R}$} & \multirow[b]{2}{*}{ R Square } & \multirow[b]{2}{*}{$\begin{array}{c}\text { Adjusted R } \\
\text { Square }\end{array}$} & \multirow[b]{2}{*}{$\begin{array}{l}\text { Std. Error of } \\
\text { the Estimate }\end{array}$} & \multicolumn{5}{|c|}{ Change Statistics } \\
\hline & & & & & $\begin{array}{l}\text { R Square } \\
\text { Change } \\
\end{array}$ & FChange & df1 & $\mathrm{df2}$ & Sig. F Change \\
\hline 1 & $.575^{\mathrm{a}}$ & .331 & .310 & 6.96049 & .331 & 15.814 & 1 & 32 & .000 \\
\hline
\end{tabular}

Tabel 5. Model Summary

Dari tabel Coefficients dilampiran secara individual variabel daya ledak otot terhadap Keterampilan Smash, didapat nilai sig. 0,000. Ternyata nilai sig. 0,000 lebih kecil dari nilai probabilitas 0,05 atau nilai 0,05 > 0,000, maka Ha diterima dan Ho ditolak artinya koefisien analisis jalur adalah signifikan. Jadi daya ledak otot tungkai berkontribusi terhadap Keterampilan Smash.

\section{$X_{2}$ Terhadap Y}

Uji secara individual ditunjukkan oleh tabel Coeficients, bahwa hasil koefisien jalur $p_{y \times 3}=0,001$, Hipotesis penelitian yang akan diuji dirumuskan berbentuk hipotesis statistik sebagai berikut:

$$
\begin{aligned}
& \text { Ha: } p_{y x 2}>0 \\
& \text { Ho: } p_{y x 2}=0
\end{aligned}
$$

Hipotesis bentuk kalimat

\begin{tabular}{|c|c|c|c|c|c|c|c|c|c|}
\hline \multirow[b]{2}{*}{ Model } & \multirow[b]{2}{*}{$\mathrm{R}$} & \multirow[b]{2}{*}{ R Square } & \multirow[b]{2}{*}{$\begin{array}{l}\text { Adjusted R } \\
\text { Square }\end{array}$} & \multirow[b]{2}{*}{$\begin{array}{l}\text { Std. Error of } \\
\text { the Estimate }\end{array}$} & \multicolumn{5}{|c|}{ Change Statistics } \\
\hline & & & & & $\begin{array}{l}\text { R Square } \\
\text { Change } \\
\end{array}$ & F Change & df1 & $\mathrm{df} 2$ & Sig. F Change \\
\hline 1 & $.539^{\mathrm{a}}$ & .291 & .269 & 7.16484 & .291 & 13.126 & 1 & 32 & .001 \\
\hline
\end{tabular}

Ha: Motivasi Berprestasi berkontribusi terhadap Keterampilan Smash

Ho: Motivasi Berprestasi tidak berkontrbusi terhadap Keterampilan Smash.

Tabel 6. Model Summary ${ }^{b}$

a. Predictors: (Constant), Motivasi Berprestasi

b. Dependent Variable: Smash Bola Voli 
Dari tabel pengaruh Motivasi Berprestasi terhadap hasil Keterampilan Smash Bola Volipada lampiran dengan Coefficients, didapat nilai sig. 0,001. Ternyata nilai sig. 0,001 lebih kecil dari nilai probabilitas 0,05 atau nilai 0,05 > 0,001, maka Ha diterima dan Ho ditolak artinya koefisien analisis jalur adalah signifikan. Jadi Motivasi Berprestasi berkontribusi terhadap Keterampilan Smash.

Hasil uji hipotesis dan Kerangka hubungan kausal empiris antara $X_{1}$, dan $X_{2}$ terhadap $Y$ dapat dibuat melalui persamaan struktural Model-1 sebaga berkut :

Kaidah pengujian signifikansi : Program SPSS versi 17.0 ditunjukkan oleh Model Summary

Tabel 7. Summary

\begin{tabular}{|c|c|c|c|c|c|c|c|c|c|}
\hline \multirow[b]{2}{*}{ Model } & \multirow[b]{2}{*}{$\mathrm{R}$} & \multirow[b]{2}{*}{ R Square } & \multirow[b]{2}{*}{$\begin{array}{l}\text { Adjusted R } \\
\text { Square }\end{array}$} & \multirow[b]{2}{*}{$\begin{array}{l}\text { Std. Error of } \\
\text { the Estimate }\end{array}$} & \multicolumn{5}{|c|}{ Change Statistics } \\
\hline & & & & & $\begin{array}{l}\text { R Square } \\
\text { Change } \\
\end{array}$ & F Change & df1 & $\mathrm{df} 2$ & Sig. F Change \\
\hline 1 & $.690^{\mathrm{a}}$ & .476 & .424 & 6.35942 & .476 & 9.093 & 3 & 30 & .000 \\
\hline
\end{tabular}

a. Predictor: (constant). Motivasi Berprstasi, Daya Ledak Otot

b. Dependent Variable: Smash Bola Voli

$R_{\text {aquare }}=0,476$ dan pada tabel anova diperoleh nilai $F$ sebesar 9,093 dengan nilai probabilitas $($ sig) $=0,000$ karena nilai sig $<0,05$, maka keputusannya adalah Ho ditolak dan Ha diterima. Oleh sebab itu, pengujian secara individual dapat dilakukan.

$$
\begin{aligned}
\text { Struktur Model-1:Y } & =p_{y \times 1} \mathrm{X}_{1}+p_{y \times 2} \mathrm{X}_{2}+p_{y} \varepsilon_{1} \\
& =0,000 \mathrm{X}_{1}+0,001 \mathrm{X}_{2}+0,524 \varepsilon_{1}
\end{aligned}
$$

Nila $R^{2}$ yx3.x1.x2 atau $R_{\text {square }}$ dapat dilhat pada tabel Model Summarib ${ }^{b}$ Untuk mencari nlai $p_{y} \varepsilon_{7}$ (varabel sisa) ditentukan denggan rumus sebagai berikut :

$$
\text { Rumus : } p_{y} \varepsilon_{1}=1-R_{\text {square }}=1-0,476=0,524
$$

\section{PEMBAHASAN}

Daya ledak merupakan sebagai unsur pendukung suatu gerak tertentu maupun sebagai unsur utama dalam upaya pencapaian teknik gerak yang sempurna, khususnya cabang olahraga permainan bola voli. Bompa dalam Syafruddin (2011:102) mendefenisikan "daya ledak sebagai produk dari dua kemampuan yaitu kekuatan (strength) dan kecepatan (speed) untuk melakukan force maksimum dalam waktu yang cepat". Dapat disimpulkan bahwa daya ledak tungkai merupakan perpaduan antara kecepatan dan kekuatan pada tungkai, daya ledak tungkai sangat penting di setiap aktifitas pada cabang olahraga terutama yang mengharuskan menggunakan 
tungkai kaki. Untuk mendapatkan tolakan yang kuat dan kecepatan yang tinggi seorang atlit harus memiliki daya ledak yang besar, jadi daya ledak otot tungkai sebagai tenaga pendorong pada saat melakukan tolakan pada saat melompat dalam melakukan smash bola voli. Dalam smash bola voli, Jika sorang atlet tidak memiliki daya ledak yang baik dalam teknik dasar smash bola voli, maka sudah dapat dipastikan lompatan yang dilakukan oleh atlet tersebut tidak akan maksimal dan tidak mampu melakukan smash dengan maksimal.

Dari hasil penelitian yang telah dilakukan pada variabel daya ledak otot tungkai dan Hasil Keterampilan Smash Bola Voli Putra Klub Huha Pekanbaru, ditemukan bahwa terdapat pengaruh langsung daya ledak otot $\left(\mathrm{X}_{1}\right)$ terhadap hasil Keterampilan Smash Bola Voli (Y) sebesar 0,331. Hal ini terlihat pada Tabel Coffesient yang menunjukan nilai sig. 0,005. Ternyata nilai sig. 0,005 lebih kecil dari nilai probabilitas 0,05 atau nilai 0,05 $>$ 0,000, maka Ha diterima dan Ho ditolak artinya koefisien analisis jalur adalah signifikan. Jadi daya ledak otot tungkai berpengaruh terhadap Keterampilan Smash bola voli Putra Klub Huha Pekanbaru.

Hal ini menunjukkan bahwa daya ledak otot tungkai merupakan unsur kemampuan fisik yang dominan dan memiliki pengaruh yang signifikan terhadap Keterampilan Smash. Jika dilihat dari pengaruh daya ledak otot tungkai dengan hasil Keterampilan Smash Bola Voli yaitu ditemui pengaruh yang kuat yaitu sebesar 0,1095 atau $10,95 \%$

Penulis tidak hanya melihat dari hubungan dan sumbangan dari temuan penelitian ini saja, akan tetapi dilanjutkan pada pengaruh dari masing-masing variabel. Pada bahasan variabel kekuatan ini berdasarkan kajian teori, kerangka teoritik serta hipotesis yang diajukan dalam penelitian ini hasil penelitian ini dapat diterima kebenarannya secara empiris. Daya ledak otot tungkai kaki yang dimiliki oleh atlet yang juga merupakan salah satu komponen kemampuan fisik yang sangat diperlukan dalam smash bola voli

Motivasi berprestasi yaitu ditandai oleh keinginan untuk mencapai standar keunggulan yang tinggi dan untuk mencapai tujuan yang unik. Motivasi berprestasi bisa dianggap sebagai perpindahan untuk mendekati keberhasilan atau kapasitas untuk mendapatkan kebanggaan dalam pemenuhan ketika kesuksesan dicapai dalam 
suatu kegiatan. Motivasi untuk berprestasi merupakan kebutuhan yang bersifat sosial sangat dibutuhkan dalam olahraga, motivasi berprestasi ini merupakan upaya manusia untuk berprestasi atau mencari sesuatu yang lebih dari manusia lainnya. Motivasi merupakan "needs for achievement" yaitu keinginan individu untuk mencapai sukses dengan tujuan berhasil dalam persaingan yang didasarkan pada suatu ukuran keunggulan ( standard of excelence). Motivasi Berprestasi yang baik, maka pemain itu akan dapat mengelolah emosionalnya dengan baik walaupin dalam keadaan depresis sekalipun. Motivasi berprestasi menimbulkan semangat yang positif dalam latihan maupun dalam pertandingan. singkatnya apabila Motivasi Berprestasinya baik maka atlet tersebut akan mudah dalam mencapai prestasi dalam olahraga permainan khususnya permainan bola voli..

Dari hasil penelitian yang telah dilakukan pada variabel Motivasi Berprestasi dan Hasil Keterampilan Smash bola voli pada atlet bola voli putra klub huha pekanbaru, ditemukan bahwa terdapat pengaruh langsung Motivasi Berprestasi $\left(\mathrm{X}_{2}\right)$ terhadap hasil Keterampilan Smash Bola Voli (Y) sebesar 0,291. Hal ini terlihat pada Tabel Coffesient yang menunjukan nilai sig. 0,001. Ternyata nilai sig. 0,005 lebih kecil dari nilai probabilitas 0,05 atau nilai 0,05 > 0,001, maka Ha diterima dan Ho ditolak artinya koefisien analisis jalur adalah signifikan. Jadi Motivasi Berprestasi berpengaruh langsung terhadap Keterampilan Smash. Hasil penelitian ini menunjukkan bahwa Motivasi Berprestasi merupakan unsur kemampuan fisik yang cukup penting dan memiliki hubungan dan pengaruh terhadap Keterampilan Smash. Jika dilihat dari hubungan serta kontribusinya kesimbangan dengan hasil Keterampilan Smash Bola Voli ditemui hubungan sebesar Rsquare 0,084 atau 8,40\%.

Pada bahasan variabel Motivasi Berprestasi ini berdasarkan kajian teori, kerangka teoritik dalam penelitian ini dapat diterima kebenarannya secara empiris, bahwa Motivasi Berprestasi memiliki Hubungan, kontribusi dan pengaruh terhadap Keterampilan Smash. Berdasarkan hasil temuan ini Hipotesis yang diajukan dalam penelitian ini diterima secara empiris. Dapat diartikan bahwa tanpa motivasi berprestasi yang baik, mustahil seorang atlet dapat merealisasikan hasil smash bola voli yang baik pada atlet bola voli putra klub Huha pekanbaru. 
Daya ledak tungkai merupakan perpaduan antara kecepatan dan kekuatan pada tungkai, daya ledak tungkai sangat penting di setiap aktifitas pada cabang olahraga terutama yang mengharuskan menggunakan tungkai kaki. Untuk mendapatkan tolakan yang kuat dan kecepatan yang tinggi seorang atlit harus memiliki daya ledak yang besar, jadi daya ledak otot tungkai sebagai tenaga pendorong pada saat melakukan tolakan pada saat berlari atau merubah langkah pada saat lompat. Daya ledak otot dipengaruhi oleh kekuatan otot, kecepatan kontraksi otot sehingga semua faktor yang mempengaruhi kedua hal-hal tersebut akan mempengaruhi daya otot. Jadi daya otot adalah kualitas yang memungkinkan otot atau sekelompok otot untuk melakukan kerja fisik secara tiba-tiba. Dalam melaksanakan keterampilan Smash Bola Voli diperlukan gerakan yang dilakukan secara cepat misalnya gerakan yang dilakukan pada saat tolakan saat melompat. Pemakaian daya otot ini dilakukan dengan tenaga maksimal dalam waktu singkat dan pendek. Daya ledak otot yang baik akan mempengaruhi kualitas psikologi atlet dalam pelaksanaan smash tersebut. Hal ini berkaitan dengan motivasi prestasi dalam mengikuti dan melaksanakan aktivitas olahraga latihan maupun dalam pertandingan. daya ledak otot yang bagus akan menimbulkan semangat yang tinggi, kepercayaan diri yang tinggi dan faktor psikologi positif lainnya yang berimplikasi pada tinggi nya kualitas permainan bola voli khususnya keterampilan smash bola voli.

Dari hasil penelitian yang telah dilakukan pada variabel daya ledak otot dan Motivasi Berprestasi pada atlet bola voli putra klub Huha Pekanbaru, ditemukan bahwa terdapat pengaruh langsung Daya Ledak Otot $\left(\mathrm{X}_{1}\right)$ terhadap motivasi berprestasi $\left(\mathrm{X}_{2}\right)$ sebesar 0,370. Hal ini terlihat pada Tabel Coffesient yang menunjukan nilai sig. 0,000. Ternyata nilai sig. 0,000 lebih kecil dari nilai probabilitas 0,05 atau nilai 0,05 $>0,000$, maka $\mathrm{Ha}$ diterima dan $\mathrm{H}_{0}$ ditolak artinya koefisien analisis jalur adalah signifikan. Jadi variabel daya ledak otot tungkai berpengaruh langsung terhadap variabel motivasi berprestasi pada atlet bola voli putra klub Huha Pekanbaru. Hal ini menunjukkan bahwa daya ledak otot tungkai merupakan unsur kemampuan fisik yang dominan dan memiliki pengaruh yang signifikan terhadap Motivasi Berprestasi. Jika dilihat dari pengaruh daya ledak otot tungkai dengan Motivasi Berprestasi yaitu ditemui pengaruh yang kuat yaitu sebesar $R_{\text {square }} 0,1369$ atau $13,69 \%$. 
Pada bahasan variabel daya ledak otot tungkai ini berdasarkan kajian teori, kerangka teoritik serta hipotesis yang diajukan dalam penelitian ini hasil penelitian ini dapat diterima kebenarannya secara empiris. Daya ledak otot tungkai kaki yang dimiliki oleh atlet juga merupakan salah satu komponen kemampuan fisik yang sangat diperlukan dalam memperoleh Motivasi Berprestasi yang baik pula.Berdasarkan hasil pengujian hipotesis secara bersama-sama maupun individual ternyata daya ledak otot tungkai dan Motivasi Berprestasi berpengaruh signifkan terhadap Keterampilan Smash. Persamaan struktural dari hasil analisis jalur dari daya ledak otot tungkai, Koordinasi Mata-Tangan dan Motivasi Berprestasi terhadap hasil hasil Keterampilan Smash Bola Voliadalah sebagai berikut:

$Y=0,000 X_{1}+0,001 X_{2}+0,524 \varepsilon_{1}$

Besarnya kontribusi variabel daya ledak otot tungkai dan Motivasi Berprestasi secara bersama-sama terhadap hasil Keterampilan Smash Bola Voli adalah sebesar $R_{\text {square }}=0,476 \times 100=47,60 \%$ sedangkan $52,40 \%$ sisanya merupakan pengaruh dari variabel-variabel lain selain dari variabel daya ledak otot tungkai dan Motivasi Berprestasi. Variabel lain yang dapat mempengaruhi keterampilan smash bola voli antara lain teknik secara efektif dan efisien sesuai dengan tahapan seperti: posisi tubuh, gerakan tungkai, gerakan lengan, gerakan koordinasi, panjang tungkai dll.

\section{KESIMPULAN}

Penarikan kesimpulan dilakukan berdasarkan hasil temuan penelitian dengan variabel eksogen terdiri dari daya ledak otot tungkai $\left(\mathrm{X}_{1}\right)$ dan motivasi berprestasi $\left(\mathrm{X}_{2}\right)$. Variabel endogen terdiri dari keterampilan smash bola voli (Y): 1)Terdapat pengaruh positif antara daya ledak otot tungkai $\left(\mathrm{X}_{1}\right)$ terhadap keterampilan smash bola voli $(\mathrm{Y})$ Pada Atlet Bola Voli Putra Klub Huha Pekanbaru. 2) Terdapat pengaruh positif antara rasa motivasi berprestasi $\left(\mathrm{X}_{2}\right)$ terhadap keterampilan smash bola voli $(\mathrm{Y})$ pada atlet bola Voli Putra Klub Huha Pekanbaru. 3) Terdapat pengaruh positif antara daya ledak otot tungkai $\left(\mathrm{X}_{1}\right)$ terhadap motivasi berprestasi $\left(\mathrm{X}_{2}\right)$ Pada Atlet Bola Voli Putra Klub Huha

Pekanbaru. Dengan demikian keterampilan smash bola voli dapat ditingkatkan melalui peningkatan daya ledak otot tungkai, koordinasi mata dan tangan dan motivasi berprestasi. 


\section{HAMBATAN DAN KENDALA}

Tidak ada menemukan kendala dalam penelitian ini.

\section{DAFTAR PUSTAKA}

Ahmadi, Nuril. Panduan Olahraga Bolavoli. Solo:Era Pustaka Utama, 2007.

Undang-Undang Nomor 3 tahun 2005 tentang Sistem Keolahragaan Nasional pasal 25 ayat 4.Palao, J.M, Santos, J.A, y Ureña, A, Effect Of Team Level On Performance Of Skills InVolleyball, International Journal of Performance Analysis of Sport. Spain: Catholic University San Antonio of Murcia, Granada University 2004.

Beutelstahl, Dieter. Belajar Bermain Bola Volley. Bandung: CV Piobir Jaya, 2008.

Hardian, Crisnan. Pendidikan Jasmani Olahraga dan Kesehatan. Depok:Arya Duta, 2011.

Anandita, F,P. Mengenal Olahraga Voli. Jakarta:Quadra, 2010.

Suarsana I Made, Addriana Bulu Baan, Pengaruh Latihan Kekuatan Otot Lengan Terhadap Ketepatan Smash dalam Permainan Bola Voli Club Sigma Palu, EJournal Tadulako Physical Education, Health And Recreation, Volume 1, Palu Sulawesi Tengah:Universitas Tadulako. 2013.

Viera, Barbara, L. Dan fergusson, Bonnie Jill. Bolavoli Tingkat Pemula.Jakarta: Rajagrafindo Persada.2000.

Syafrudin, Ilmu Kepelatihan Olahraga, Padang:UNP Press,2011.

Bompa, Tudor O dan G.Gregory Haff, Periodization Theory and Methodology of Training.

Dupuis Cedric and Claire Tourny-Chollet, Increasing Explosive Power of the Shoulder in Volleyball Players. Strength and Conditioning Journal. France: University of Medicine Rouen. 2003.

Asrori, Mohammad. Psikologi Pembelajaran, Bandung: CV Wahana Prima 2007.

Fernando Claver, Ruth Jiménez, Cognitive And Motivational Variables As Predictors Of Performance In Game Actions In Young Volleyball Players. European Journal of Human Movement. Vol.35, 68-84. Faculty of Sport Science:University of Extremadura. 2015

W. Brewer Britton, Sport Psychology. USA, Departement of Psychology Springfield College, 2009 
Patsiaoulus Asterios, Person-Centered Support And Athletes' Motivation For Performance, Perceptual And Motor Skill. Greece: University Of Thessaly. 2008.

Pelletier, Fortier et all, Toward a New Measure of Intrinsic Motivation, Extrinsic Motivation, and Amotivation in Sports:The Sport Motivation Scale (SMS), Journal Of Sport \& Exercise Psychology. Human Kinetics Publishers. 1995.

Mustaqim, Enjang, Ahmad. Hubungan antara kekuatan otot lengan, koordinasi matatangan dan motivasi berprestasi dengan keterampilan servis atas bola voli, Tesis, PPS UNJ. 2015.

Sheppard Jeremy m., John b. Cronin Et All, Relative Importance Of strength,Power, And Anthropometric Measures To Jump Performance Of Elite Volleyball Players, Journal Of Strength And Conditioning Research. Australian: The Journal Of Strength And Conditioning Research. 2008.

Kuhlmann Claas, Karen Roemer, Thomas L. Milani, Aspects Of A Three Dimensional Motion Analysis Of The Volleyball Spike In High Level Competition. XXV ISBS Symposium. Brazil: Institute Of Sports Science, Chemnitz University Of Technology. 2007. 


\section{LAMPIRAN}

\section{Informasi Tentang Penulis:}

Yan Bastian, S.Pd, M.Pd:

Email: yanbastian030190@gmail.com; Sekolah Menengah Atas Negeri 1 Palmatak Kabupaten Kepulauan Anambas, Kepulauan Riau;Alamat: Jl. Yusuf, Nomor 88, Desa Tebang, Kabupaten Kepulauan Anambas, Kepulauan Riau, 29783. 